\title{
An Analysis on Anti-bullying Actions in Schools in the U.K and Its Enlightenment to China
}

\author{
Taking Wales as an Example*
}

\author{
Ruishu Wang \\ School of Humanities and Law \\ Foreign Studies College \\ Northeastern University \\ Shenyang, China
}

\author{
Wanbing Shi** \\ School of Humanities and Law \\ Northeastern University \\ Shenyang, China \\ **Corresponding Author
}

\begin{abstract}
Schools in the U.K have formed plenty of practical approaches on anti-bullying to prevent and handle school bullying. Meanwhile, they have made their own policies of antibullying which contain responsibilities and solving processes. Also, schools have conducted training of anti-bullying for teachers and staff to improve their coping skills. In addition, schools have conducted anti-bullying education for students to prevent school bullying. Moreover, schools have enhanced the psychological counseling for both victims and bullies to help them recover as soon as possible. Meanwhile, cooperating with parents and social organizations has been one of effective methods for anti-bullying. Compared to schools in the U.K., the schools in China need to make clear policies of anti-bullying, enhance the training and education of the knowledge and skills of anti-bullying and gather forces in society to set up a multiple preventing school bullying system.
\end{abstract}

Keywords-the U.K; school bullying; anti-bullying actions; enlightenment

\section{INTRODUCTION}

School bullying is a social issue that many countries are facing and is plaguing students' education and management in schools. Schools in various regions of the UK have made remarkable achievements on preventing and controlling school bullying. Their experience and methods are worth learning from. This article takes the Wales region as an example, analyzes and studies the anti-bullying measures in UK campuses, and provides feasible ideas for improving the anti-bullying system in Chinese campuses combining China's national conditions.

\section{DEFINITION OF BULLYING AND ITS BAD INFLUENCE ON STUDENTS}

\section{A. Definition of Bullying}

Professor Peter Smith of the University of London defined bullying as the malicious, aggressive, long-term or repetitive

*Fund Project: Research result of key foundation project for the second teaching reform and education quality evaluation research of Education Evaluation Association in Liaoning province "Research on Evaluation and Reform of Humane Quality Elective Courses in Universities Led by Core Literacy". behavior that includes harms on body, psychology, or emotion and is done by an individual or group in order to harm, isolate or intimidate another person or group[1]. Well-known scholar Elliot defines bullying as a negative or infringing, continuous or even organized act committed by a student or group on other individuals or groups in order to achieve control or intimidation [2].

\section{B. The Bad Influence of Bullying on Students}

1) Influence on people being bullied: Bullying does much harm to or has great influence on bullied people. First of all, bullied people often experience tremendous psychological pressure. In 2003, Rigby conducted a large-scale survey of the impact of school bullying on students in England and Wales in the United Kingdom. The results showed that $25 \%$ of students often feel fear after being bullied; $31 \%$ of bullied students feel anxious, depressed, lonely or insecure more frequently than other students. Some victims may even suffer from insomnia or cry frequently[3]. Second, it is difficult for bullied people to reintegrate into campus life. Many victims choose to skip school or do not want to go to school to avoid being harmed again [4]. Compared with other students, they shyer or lack self-confidence, and it is difficult for them to make friends. In cooperation with others, they are also at a distinct disadvantage.

2) Influence on bullies: Bullying not only harms the victim, but also has a negative impact on the bully. Rigby said: Bullying will have a negative impact on the mood of bullies. Some bullies are ashamed or regretful after bullying other students; some bullies may feel anxious about being revenged after bullying others, and some bullies may feel lonely because of being accused and rejected by other peers after they bullied the students[5].

3) Influence on bystanders: The adverse influence of bullying on bystanders cannot be ignored. According to a campus survey conducted by Berger in England in 2007, 83\% of onlookers are panicked, anxious, or frustrated about campus life after seeing bullying in campus. Many onlookers fear to become the next goal of campus bullying [7]. Second, 
some spectators chose to be silent or had to join the bullies when school bullying occurred because they feared to be bullied, but these behaviors often make them feel very embarrassed and uneasy [8].

To sum up, campus bullying is a social phenomenon with high hazards, and it will have adverse influence on the bullied students, onlookers, and bullies. This shows that it is necessary for schools to implement anti-bullying measures.

\section{THE SPECIFIC CONTENT OF THE ANTI-CAMPUS BULLYING MEASURES IN WALES, UK}

Wales is one of the political entities in the United Kingdom, with approximately 466,500 underage students in the district [9]. In order to provide a good campus environment for children, relevant departments at all levels in Wales have adopted a series of effective measures to reduce and prevent the occurrence of school bullying.

\section{A. Formulating Relevant Policies and Clarifying the Handling Methods}

Each of the educational departments in Wales has policies about anti-bullying. The handling methods for school bullying are clearly defined in the policies.

The Welsh Assembly Government in 2010 clearly stated in the "Practical approaches to behavior management in the classroom" document that teachers should adopt a "four-step" approach when bullying occurs in the classroom. First, actively deal with the emergency. Once bullying occurs, teachers or faculty must immediately intervene. Second, investigate the incident as soon as possible and ensure the fairness in the investigation process. Third, provide a clear solution and involve relevant students in the resolution of the incident so that bullies can fully recognize the seriousness of their behaviors. Fourth, follow up, teachers or staffs need to continue to observe, return visits, etc. after handling the incident, to know the status quo of relevant students, and help them re-establish the relationship [10].

Estyn is an education department affiliated with the Welsh government. Its main responsibility is to test the education quality of schools in Wales. In 2014, Eston introduced the "Action on Bullying" policy, which clearly gives five suggestions for schools to deal with bullying. First of all, schools, teachers, students, and parents must all know more about bullying. Secondly, teachers or staff should regularly interact with students and parents to know the actual bullying phenomenon in school and its degree, and to collect the opinions of students and parents. Third, set up related courses, discuss related issues, and provide opportunities for students to participate, such as setting up the peer mutual assistance system. Fourth, cooperate with external agencies to jointly handle related issues. Fifth, ensure that relevant measures and procedures in all schools are in compliance with the requirements of the "Equality Act" [11].

In addition, schools in Wales have also formulated antibullying policies and designed related processes. We will take Ysgol Friars middle school as an example in this section. After the school bullying occurs, the specific processing flow is as follows. First of all, after discovering the bullying phenomenon or receiving a bullying report, the teacher should talk with the students concerned to know the details of the incident. Second, talk to two students at the same time. During the conversation, students should be given the opportunity to express their opinions and propose solutions. Teachers or staff should let students know more about and pay more attention to anti-bullying to avoid the recurrence of school bullying. Third, meet with the parents of both bullies and victims to inform the situation of the incident. Fourth, record the bullying incident and report it to related departments. Fifth, follow up. If the above strategies fail or the bully continues his behaviors, the school should take appropriate measures, such as suspending or expelling the bully. [12]

\section{B. Strengthening the Education for All Parties to Prevent Bullying}

In order to prevent school bullying, various schools in Wales actively use educational means to make teachers and students know more about school bullying and improve their anti-bullying ability. The means mainly include training for staff in anti-bullying knowledge, anti-bullying education for all students, and education for victims and bullies.

1) Training for staff in anti-bullying knowledge: The document of Welsh Assembly Government "Anti-bullying Guidelines Circular 23 2003" explicitly states that school staff are obliged to accept anti-bullying knowledge training organized by the school. The main training content includes legal responsibilities, school anti-bullying policies and specific solutions [13]. Therefore, most schools in Wales will train staff in anti-bullying knowledge before or after they start their work. For example, Ysgol Friars Middle School conducts anti-bullying training for newly recruited staff, covering the concepts and harms of bullying, the identification of bullying, the processing procedures, and the prevention for school bullying. In addition, the school will train all staff in the new form of bullying (such as cyberbullying) and its solutions, and constantly update staff's anti-bullying knowledge and methods [14].

2) Anti-bullying education for all students: Schools in Wales conduct anti-bullying education for all students, mainly through setting up PSE courses, holding anti-bullying activities, establishing peer mutual assistance systems, and carrying out anti-bullying activities cooperating with social institutions.

First, the PSE courses. Most schools in the UK offer antibullying routine courses such as PSE (Personal and Social Education), PSHE (Personal, Social and Health Education) and PSED (Personal, Social and Emotional Development). Among them, schools in Wales mainly offer PSE courses. The purpose of the PSE course is to help students establish correct values and attitudes towards life so that they can respect themselves and others, live healthily and safely, accept different opinions and disagreements, face difficulties positively, strengthen self-control, and become good students and citizens [15]. The schools aim to improve students' 
qualities through PSE courses and curb the occurrence of school bullying from the source.

Second, anti-bullying teaching activities. They mainly include specialized activities and related extra-curricular activities. For example, anti-bullying discussions are regularly held in the classroom to let students discuss the dangers of bullying, how to deal with bullying, and how to establish a safe campus environment. In addition, the school regularly organizes anti-bullying extra-curricular activities based on actual conditions, such as organizing students to draw antibullying slogans and posters, holding activities which enable students to establish peer trust, and holding role-playing activities [16] which can enhance students' awareness of antibullying.

Third, establishing peer mutual assistance systems. Encourage students to actively participate in school antibullying management and carry out anti-bullying work together with the school by training students in anti-bullying knowledge and awareness [17]. For example, the school regularly trains some senior students to help junior students who need help in their studies and lives. Enhance the friendship between students and reduce the occurrence of school bullying through the establishment of peer mutual assistance systems.

Fourth, holding anti-bullying activities in cooperation with social institutions. Most schools in Wales cooperate with related social institutions and regularly organize anti-bullying activities. For example, local community police are invited to conduct safety knowledge popularization for students; or antibullying social groups are invited to conduct campus antibullying lectures, etc. [18].

3) Education for victims: After a bullying incident occurred, the victimized student usually experiences anxiety, frustration, lack of security, or feelings of school-weariness. He needs to be helped by the school in time[19]. Schools usually provide psychological counseling for the victimized students to help them re-establish self-esteem and selfconfidence, ensuring that they can return to schools and adapt to campus life as soon as possible[20]. For students who are deeply affected by the bullying incident and have difficulty in continuing to go to school, the school will seek assistance from external agencies and let them provide more professional guidance and treatment for students to help them overcome psychological pressure and be physically and mentally healthy again. In addition, the school will closely communicate and cooperate with the parents of the victims to help them return to school as soon as possible.

4) Education for bullies: Bullies whose behaviors are not corrected in time will usually do worse bullying[21]. After the incident occurred, the school will first educate the bullies and correct their behavior to make them aware of their wrong behavior and its harm. Second, schools often regulate the relationship between bullies and victims and promote the changing in ideas and behaviors of the bullies.[22] In addition, the school will hire professionals to provide psychological and emotional control counseling for bullies, to help them better control their emotions and to avoid recurrence of bullying.

\section{Other Related Measures}

1) Multi-party cooperation: Multi-party cooperation is a method commonly used by schools in Wales in anti-bullying actions, such as the cooperation with local police. The police are invited to regularly communicate with students about recent safety issues, provide relevant solutions and guide students to actively seek assistance from local police if school bullying or off-campus bullying occurs; The cooperation with relevant social organizations, such as Bullying Intervention Organization (BIG). Solicit professional opinions or seek help from the organization when handling bullying incidents; cooperate with local psychological counseling organizations to let them provide regular psychological counseling to bullied students to help them recover mental heath; Positively communicate with parents and inform them the measures and procedures conducted by the school to prevent and deal with bullying incidents, regularly contact with parents via telephone or e-mail to know the true state of students and parents' opinions [23].

2) Set anonymous mailbox: Some schools in Wales will set up anonymous mailboxes to receive information on bullying incidents in campus. Students can send anonymous letters to provide relevant information. This approach is mainly aimed at victims who are ashamed to report the incident face to face and bystanders who are willing to provide information about the incident but are concerned about the exposure of their names[24]. By setting up an anonymous mailbox, the school encourages more students to speak out the bullying they have experienced or seen, so that the school can better deal with the bullying incidents.

\section{THE ENLIGHTENMENT OF UK'S CAMPUS ANTI- BULLYING MEASURES TO CHINA}

\section{A. Improve Policies and Regulations on School Bullying}

In the United Kingdom, there are clear legal provisions for school bullying. From the regional governments to schools, each of them has formulated relevant policies on school bullying. The policies clarify the specific steps and processes for dealing with bullying by departments at different levels. They have achieved that there are laws and principles to follow. However, the "Guidance on Prevention and Control of Bullying and Violence in Elementary and Middle Schools" issued by the Ministry of Education and other eight departments in 2016 pointed out that at present, the primary and secondary schools in some regions in China have weaknesses in improving the anti-bullying system and the formation of cooperative forces [25]. Therefore, in the face of school bullying, China should improve relevant laws and introduce specific policies for anti-bullying as soon as possible so that schools can follow laws and principles in handling school bullying incidents. 


\section{B. Strengthening Anti-bullying Education for Students}

Most schools in the UK strengthen anti-bullying education by setting up regular courses or carrying out relevant teaching activities, which can help students know what bullying is and how to deal with bullying, and establish self-protection awareness. In addition, the school will provide psychological counseling to those who are bullied and help them overcome psychological pressure and return to school as soon as possible. Chinese schools should vigorously conduct antibullying education to help students identify and respond to bullying, understand the adverse effects of bullying and the consequences that need to be undertaken. In addition, it is necessary to strengthen the education for students' mental health and to intervene in time if problems are found.

\section{Improve Teachers' Ability to Handle School Bullying Incidents}

Teachers play an important role in handling school bullying incidents. Chinese schools should strengthen the training for teachers' ability to prevent and respond to school bullying so that teachers can identify campus bullying in time and intervene and correct relevant behaviors as soon as possible. In addition, teachers should be able to promptly find changes in students' thoughts, psychology, and emotions, communicate with them in time, and give them help when necessary.

\section{Multi-party Cooperation and Joint Control}

In the control of school bullying, Chinese schools can cooperate with family and society, such as cooperating with parents, police or social organizations, etc., to jointly control bullying behavior, and establish a more professional and comprehensive processing mechanism.

\section{CONCLUSION}

In summary, the measures adopted by British schools in the control of school bullying are relatively more mature and complete. Their experience and methods are worth learning from. China can learn from them and combine them with China's national conditions, gather the power of governments, schools, families and the society to control school bullying and gradually realize that there are laws and principles to obey and teachers help students with love.

\section{REFERENCES}

[1] Smith, P. 2004, 'Bullying: Recent Developments'. Child and Adolescent Mental Health, vol. 9, pp.98-104.

[2] Elliott, M. 1997, Bullying: A Practical Guide for Schools, Pitman, London.

[3] States: Physical, Verbal, Relational, and Cyber', Journal of Adolescent Health, vol. 45, pp. 368-75.

[4] Rigby, K. 2003, 'Consequences of Bullying in Schools', Can, J Psychiatry, vol. 48

[5] Warden, D. \& Mackinnon, S. 2003, 'Prosocial Children, Bullies and Victims: An Investigation of Their Sociometric Status, Empathy and Social Problem-solving Strategies', British Journal of Developmental Psychology, vol. 21, pp. 367-85.
[6] Rigby, K. 2003, 'Consequences of Bullying in Schools', Can, J Psychiatry, vol. 48.

[7] Berger, K.2007, 'Update on Bullying at School: Science Forgotten?', Developmental Review, vol. 27, pp. 90-126.

[8] Salmivalli, C. , Voeten, M. \& Poskiparta, E. 2011, 'Bystanders Matter: Associations Between Reinforcing, Defending, and the Frequency of Bullying Behavior in Classrooms', Journal of Clinical Child \& Adolescent Psychology, vol. 40, pp. 668-76.

[9] Welsh Government (2017). StatsWales[EB/OL]. [2018-01-25]. https://statswales.gov.wales/Catalogue/Education-and-Skills/Schoolsand-Teachers/Schools-Census/Pupil-Level-Annual-SchoolCensus/Schools/schools-by-localauthorityregion-type.

[10] Welsh Assembly Government 2010, Practical Approaches to Behaviour Management in the Classroom.

[11] Estyn 2014, Action on Bullying: A review of the effectiveness of action taken by schools to address bullying on the grounds of pupils' protected characteristics.

[12] Ysgol Friars 2014, Anti-bullying Policy.

[13] Welsh Assembly Government 2003, Anti-bullying Guidelines (Circular 23).

[14] Ysgol Friars 2014, Anti-bullying Policy.

[15] Welsh Assembly Government 2008, Personal and social education framework for 7 to 19 year-olds in Wales.

[16] Gwynedd Council 2008, Bullying Amongst Children and Young People in Gwynedd, pp.14.

[17] Welsh Assembly Government 2003, Anti-bullying Guidelines (Circular 23).

[18] Welsh Assembly Government 2008, Personal and social education framework for 7 to 19 year-olds in Wales.

[19] Kim, Y., Leventhal, B., Koh, Y., Hubbard, A. \& Boyce, W. 2006, 'School Bullying and Youth Violence: Causes or Consequences of Psychopathologic Behavior?', Arch Gen Psychiatry, vol. 63.

[20] Swearer, S., Espelage, D., Vaillancourt, T. \& Hymel, S. 2010, 'What Can Be Done About School Bullying? Linking Research to Educational Practice', Educational Researcher, vol.39, pp. 38-47.

[21] Salmivalli, C. 2010, 'Bullying and the peer Group: A Review', Aggression and Violent Behavior, vol. 15, pp. 112-20.

[22] Eslea M., Menesini E., Morita Y., O'Moore M., Mora-Merchán J., et al. 2004, 'Friendship and Loneliness Among Bullies and Victims: Data from Seven Countries', Aggressive Behavior, vol.30, pp. 71-83.

[23] Hunter, S. \& Boyle, J. 2010, 'Perceptions of Control in the Victims of School Bullying: The Importance of Early Intervention', Educational Research, vol. 44, pp. 323-36.

[24] Sullivan, K., Cleary, M. \& Sullivan, G. 2003, Bullying in Secondary Schools Corwin Press, London.

[25] Ministry of Education, Guiding Opinions on Prevention and control of Bullying and Violence in Elementary and Middle Schoolshttp://www.moe.edu.cn/srcsite/A06/s3325/201611/t20161111_2 88490.html. 教育部.关于防治中小学生欺凌和暴力的指导意见 [EB/OL].[2018-01-19]. 